Two new species of calcareous sponges (Porifera: Calcarea) from the deep Antarctic Eckström Shelf and a revised list of species found in Antarctic waters

Rapp, Hans Tore; Göcke, Christian; Tendal, Ole Secher; Janussen, Dorte

Published in:

Zootaxa

DOI:

10.11646/zootaxa.3692.1.9

Publication date:

2013

Document version

Publisher's PDF, also known as Version of record

Document license:

CC BY

Citation for published version (APA):

Rapp, H. T., Göcke, C., Tendal, O. S., \& Janussen, D. (2013). Two new species of calcareous sponges (Porifera: Calcarea) from the deep Antarctic Eckström Shelf and a revised list of species found in Antarctic waters. Zootaxa, 3692(1, SI), 149-159. https://doi.org/10.11646/zootaxa.3692.1.9 
http://dx.doi.org/10.11646/zootaxa.3692.1.9

http://zoobank.org/urn:lsid:zoobank.org:pub:9DF47E82-8FED-434D-8CB1-81DCBCCB2951

\title{
Two new species of calcareous sponges (Porifera: Calcarea) from the deep Antarctic Eckström Shelf and a revised list of species found in Antarctic waters
}

\author{
HANS TORE RAPP ${ }^{1,4}$, CHRISTIAN GÖCKE ${ }^{2}$, OLE SECHER TENDAL ${ }^{3} \&$ DORTE JANUSSEN $^{2}$ \\ ${ }^{\prime}$ Centre for Geobiology and Department of Biology, University of Bergen, PO Box 7800, N-5020 Bergen, Norway. \\ E-mail:hans.rapp@bio.uib.no \\ ${ }^{2}$ Forschungsinstitut und Naturmuseum Senckenberg, Senckenberganlage 25, D-60325 Frankfurt am Main, Germany. \\ E-mail: christian.goecke@senckenberg.de; dorte.janussen@senckenberg.de \\ ${ }^{3}$ Zoological Museum, SNM, University of Copenhagen, Universitetsparken 15, København Ø, DK-2100 København, Denmark. \\ E-mail: ostendal@snm.ku.dk \\ ${ }^{4}$ Corresponding author.E-mail: hans.rapp@bio.uib.no
}

\begin{abstract}
The paper reports on two new species of calcareous sponges (Porifera, Calcarea) from the Antarctic Weddell Sea, Clathrina brandtae sp. nov. and Leucetta delicata sp. nov., collected at $600 \mathrm{~m}$ depth during the ANT XXIV/2-SYSTCO expedition in January 2008. The new species are described based on a combination of morphological and molecular data. With these new additions the number of species of calcareous sponges reported from south of $50^{\circ} \mathrm{S}$ ( $\sim$ south of the Polar Front) reaches 50 species. We report an exceptionally high degree of endemism within the group, and as many as 44 out of the 50 species of calcareous sponges are solely confined to Antarctic waters. An updated list of species of calcareous sponges from the area is provided.
\end{abstract}

Key words: Clathrina brandtae sp. nov., Leucetta delicata sp. nov., SYSTCO, endemic species, Weddell Sea, deep-water sponges

\section{Introduction}

The calcareous sponges, or Calcarea Bowerbank, 1864, comprises the two sub-classes Calcinea Bidder, 1898 and Calcaronea Bidder, 1898. They all have a mineral skeleton composed entirely of calcium carbonate, consisting of free or rarely linked and cemented diactine, triactine, tetractine or polyactine spicules, sometimes in combination with a solid basal calcitic skeleton. More than almost 700 species have been described world-wide (van Soest et al. 2012), but recent investigations in poorly studied areas have indicated that the species diversity may be much higher (Wörheide \& Hooper 1999; Rapp 2006; Azevedo et al. 2009; Rapp et al. 2011). The calcareous sponges are small sponges (millimeter to centimeter scale) and have traditionally been regarded as shallow-water organisms (van Soest et al. 2012). However, calcareous sponges have also been reported from bathyal and abyssal depths in the North Atlantic, the Southern Ocean and the North Pacific (Hansen 1885; Borojevíc \& Graat-Kleeton 1965; Koltun 1970; Barthel \& Tendal 1993; Janussen et al. 2003; Rapp et al. 2011). Even though the calcareous sponges appear to be present in deep waters in all major oceans it is only in the Norwegian- and Greenland Seas that they represent a highly diverse and abundant part of the abyssal fauna (Rapp \& Tendal, unpublished data).

The monophyletic origin of the calcareous sponges has been supported by a range of molecular phylogenies (Adams et al. 1999; Manuel et al. 2003; Dohrmann et al. 2006; Voigt et al. 2012). However, several of the traditionally accepted groups at order- family- and genus level have recently been shown to be non-monophyletic (Dohrmann et al. 2006; Rossi et al. 2011; Voigt et al. 2012)

Calcarea from the deep Antarctic shelf have been reported only on a few occasions, mostly from single specimens. For example, Koltun (1976) identified two species from a depth of $603 \mathrm{~m}$ and $640 \mathrm{~m}$ off Enderby Land and Adelie Land respectively, both in the Indian Ocean sector of Antarctica. Tanita (1959) sampled one calcareous 
sponge from a depth of $570 \mathrm{~m}$ off Queen Mauds Land (Atlantic sector). Tendal described eight species from 11 stations dredged from depths of 400 to $890 \mathrm{~m}$ off Coats Land/Cape Norvegia in the eastern Weddell Sea (Tendal unpublished; partly mentioned without depth indications in Barthel et al. (1997)). The ANDEEP I-III expeditions (2002 and 2005) and SYSTCO I campaign provided new insight into the bathyal and abyssal benthic zone of the Southern Ocean, including numerous new records of the Porifera (e.g. Janussen et al. 2004; Brandt et al. 2007; Janussen \& Tendal 2007; Plotkin \& Janussen 2008; Janussen \& Reiswig 2009; Göcke \& Janussen 2011). Of particular interest was the discovery of five isolated specimens of calcareous sponges, three new to science, collected from five different bathyal and abyssal stations in the Weddell Sea (Rapp et al. 2011).

TABLE 1. List of species of Calcarea recorded in Antarctic waters south of $50^{\circ} \mathrm{S}$ (in alphabetical order). The list is based on original literature, World Porifera Database (van Soest et al. 2012), examination of original material and collections held by the authors and a re-evaluation of the records used in a recent publication on the distribution of sponges in the Southern Oceans (Downey et al. 2012). All together 50 species of calcareous sponges are considered to be part of the Antarctic sponge fauna (here defined as below $50^{\circ} \mathrm{S}$ ). As many as 44 species are considered endemic to Antarctic waters (in bold) while only six out of these 50 species have also been found elsewhere.

\begin{tabular}{|c|c|}
\hline Achramorpha glacialis Jenkin, 1908 & Leucetta apicalis Brøndsted, 1931 \\
\hline Achramorpha grandinis Jenkin, 1908 & Leucetta delicata sp. nov. \\
\hline Achramorpha nivalis Jenkin, 1908 & Leucetta gelatinosa (Jenkin, 1908) \\
\hline Achramorpha truncata (Topsent, 1908) & Leucetta pyriformis (Burton, 1932) \\
\hline Ascaltis abyssus Rapp et al., 2010 & Leucetta weddelliana Rapp et al., 2010 \\
\hline Ascaltis procumbens (Lendenfeld, 1885) & Leucettusa haeckeliana (Polejaeff, 1883) \\
\hline Breitfussia chartacea (Jenkin, 1908) & Leuconia joubini (Topsent, 1907) \\
\hline Breitfussia vitiosa (Brøndsted, 1931) & Leucosolenia aboralis Brøndsted, 1931 \\
\hline Clathrina brandtae sp. nov. & Leucosolenia australis Brøndsted, 1931 \\
\hline Clathrina broendstedi Rapp et al., 2010 & Leucosolenia discoveryi Jenkin, 1908 \\
\hline Dermatreton hodgsoni Jenkin, 1908 & Leucosolenia falklandica Breitfuss, 1898 \\
\hline Dermatreton scotti (Jenkin, 1908) & Leucosolenia macquariensis Dendy, 1918 \\
\hline Grantia hirsuta (Topsent, 1907) & Leucosolenia pilosella Brøndsted, 1931 \\
\hline Grantia transgrediens Brøndsted, 1931 & Leucosolenia solida Brøndsted, 1931 \\
\hline Jenkina articulata Brøndsted, 1931 & Megapogon crispatus Jenkin, 1908 \\
\hline Jenkina glabra Brøndsted, 1931 & Megapogon pollicaris Jenkin, 1908 \\
\hline Jenkina hiberna (Jenkin, 1908) & Megapogon raripilus Jenkin, 1908 \\
\hline Leucandra comata Brøndsted, 1931 & Megapogon villosus Jenkin, 1908 \\
\hline Leucandra conica Lendenfeld, 1885 & Soleneiscus apicalis (Brøndsted, 1931) \\
\hline Leucandra frigida Jenkin, 1908 & Soleneiscus hispidus (Brøndsted, 1931) \\
\hline Leucandra gausapata Brøndsted, 1931 & Sycantha longstaffi (Jenkin, 1908) \\
\hline Leucandra levis (Poléjaeff, 1883) & Sycetta antarctica (Brøndsted, 1931) \\
\hline Leucandra mawsoni Dendy, 1918 & Sycon antarcticum (Jenkin, 1908) \\
\hline Leucascus leptoraphis (Jenkin, 1908) & Sycon australe (Jenkin, 1908) \\
\hline Leucetta antarctica Dendy, 1918 & Sycon incrustans Breitfuss, 1898 \\
\hline
\end{tabular}

The Antarctic sponge fauna has been characterized by a high degree of endemism (Janussen \& Tendal 2007; Downey et al. 2012), many eurybathic species (Janussen \& Tendal 2007) and a circumpolar distribution pattern (Janussen \& Tendal 2007; Janussen \& Rapp 2011; Downey et al. 2012). The Weddell Sea area is of special interest from a zoogeographical point of view as it seems to be a strong link between the sponge faunas of the Antarctic and South America (Downey et al. 2012). During the recent ANT XXIV/2 (SYSTCO I) expedition (2007/08), a very rich association of invertebrates (Mollusca, Polychaeta and Porifera) was collected from a station (\#71/48-1) on the deep Eckström Shelf (eastern Weddell Sea) at $600 \mathrm{~m}$ depth. Porifera had the highest biomass and was among the 
more abundant groups, primarily due to the presence of large Demospongiae and Hexactinellida (some more than $10 \mathrm{~kg}$ in wet weight), especially of the genus Rossella (Göcke \& Janussen 2011; Göcke \& Janussen, this volume). Apart from these, an unusual "mass occurrence" of the calcareous sponges Jenkina articulata was also recorded (Janussen \& Rapp 2011). We here report on two more species of Calcarea from this locality and describe the new species Clathrina brandtae sp. nov., formerly reported as Clathrina "primordialis" at several localities in the Antarctic (Jenkin 1908; Brøndsted 1931; Koltun 1976; Barthel et al. 1997) and Leucetta delicata sp. nov. Based on published records and examination of published and unpublished collections we present a list of species of calcareous sponges found south of the Antarctic polar front $\left(\sim 50^{\circ} \mathrm{S}\right)$ (Table 1).

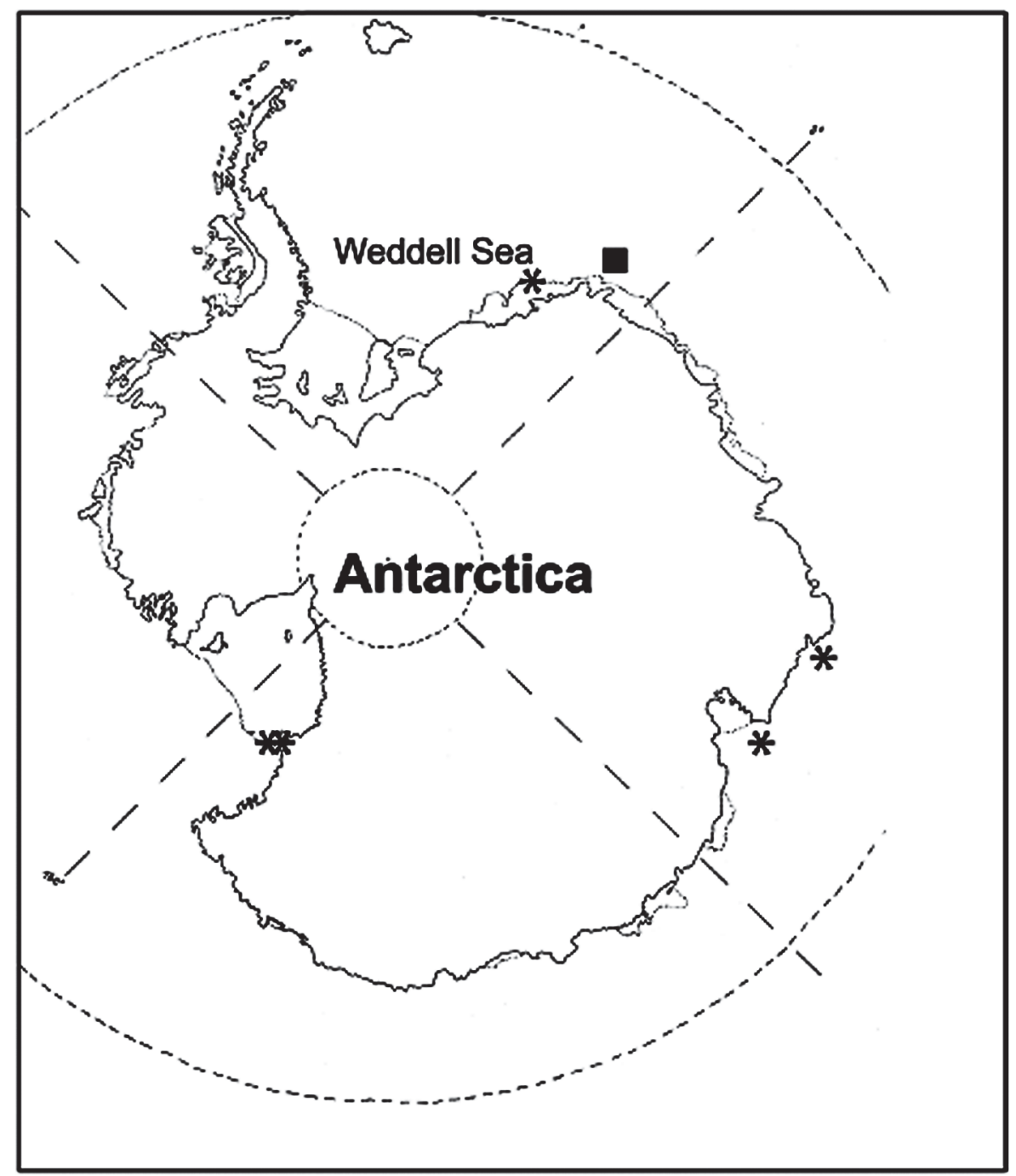

FIGURE 1. Square: Sampling location in the Weddell Sea (SYSTCO 2008) and type locality of Clathrina brandtae sp. nov. and Leucetta delicata sp. nov. Asterisks: additional known records of Clathrina brandtae sp. nov.

\section{Material and methods}

The material was collected on January the 12th 2008 with an Agassiz trawl (1.5 m width, $10 \mathrm{~mm}$ mesh size) during the ANT-XXIV/2, SYSTCO I Expedition on the Eckström Shelf (start trawling 70² 23.94' S, $8^{\circ} 19.14^{\prime} \mathrm{W}, 602.1 \mathrm{~m}$, end trawling $70^{\circ} 23.89^{\prime} \mathrm{S}, 8^{\circ} 18.67^{\prime} \mathrm{W}, 595.2 \mathrm{~m}$ ), Eastern Weddell Sea, Antarctica (Figure 1). For more details on this station (\# 71/48-1) and on other Agassiz trawl catches, see Janussen (2010) and Janussen et al. (2010). Spicule preparations and spicule measurements were made following standard procedures for calcareous sponges (e.g. Rapp 2006), and thick sections were produced from epoxy embeddings, following the standard procedures by Boury-Esnault \& Bézac (2007) and Plotkin et al. (2012). Specimens were stained with Toloudine blue after 
sectioning. The studied material is deposited at the Forschungsinstitut und Naturmuseum Senckenberg (SMF-No. 11866-11868). For barcoding purposes the internal transcribed spacer (ITS) was sequenced. DNA was extracted from ethanol-preserved specimens using the Qiagene Kit following the manufacturer's instructions. The entire region comprising the two spacers (ITS1 and ITS2) and the 5.8S ribosomal DNA was amplified by PCR with primers anchored on 18S (5' TCA TTT AGA GGA AGT AAA AGT CG 3') and 28S (5' GTT AGT TTC TTT TCC TCC GCT T 3') (Lôbo-Hajdu et al. 2004) following the procedures described in detail in Rossi et al. (2011), only with minor changes in the PCR steps. Our PCR steps included $5 \mathrm{~min}$ at $95{ }^{\circ} \mathrm{C}, 35$ cycles of $30 \mathrm{sec}$ at $94{ }^{\circ} \mathrm{C}, 30$ sec at $50-55^{\circ} \mathrm{C}$, and $1 \mathrm{~min}$ at $72{ }^{\circ} \mathrm{C}$. The obtained sequences were edited using the Lazergene program package (v.6; DNASTAR, Inc., Madison, WI, USA). The Poriferan origin of the sequences was checked by BLAST searches (http://www.ncbi.nlm.nih.gov/BLAST/).

\section{Results}

\section{Systematics}

Class Calcarea Bowerbank, 1864

Subclass Calcinea Bidder, 1898

Order Clathrinida Hartman, 1958 emend.

Family Clathrinidae Minchin, 1900

Genus Clathrina Gray, 1867

Type species: Clathrina clathrus (Schmidt, 1864).

Genus diagnosis. Clathrinidae in which the choanoderm is flat or rarely raised into conuli by the apical actines of the tetractines, but never forms true folds, at least when the sponge is in the extended state. The full-grown cormus comprises anastomosed tubes. The skeleton is composed of regular, equiangular and equiradiate triactines and/or tetractines, to which diactines and/or tripods may be added (from Borojevic et al. 2002).

Clathrina brandtae sp. nov.

(Figure 2, Table 2)

Synonyms and citations: Clathrina primordialis (Jenkin 1908 pars: 6; Brøndsted 1931 pars: 4-9; Koltun 1976 : 163; Barthel et al. 1997: 46-47); Clathrina sp. nov. 14 (Klautau et al. 2013).

Type locality: Eckström Shelf, Eastern Weddell Sea, Antarctica. SYSTCO station $71 / 48-1$ at $70^{\circ} 23.94^{\prime} \mathrm{S}, 8^{\circ}$ $19.14^{\prime} \mathrm{W}, 602.1 \mathrm{~m}$ depth to $70^{\circ} 23.89^{\prime} \mathrm{S}, 8^{\circ} 18.67^{\prime} \mathrm{W}, 595.2 \mathrm{~m}$ depth.

Type material: Holotype SMF 11867, paratype SMF 11866 (fragmented specimen), both from the type locality.

Additional material examined: EASIZ Expedition. Weddell Sea (1 incomplete specimen), st ps 39/24, 21.02.1996, $71^{\circ} \mathrm{S} 8.15^{\prime} \mathrm{W}, 118-123 \mathrm{~m}$ depth (Barthel et al. 1997).

Etymology: Named after Professor Angelika Brandt for her great efforts organizing the ANDEEP and SYSTCO expeditions.

Description: Clathrinidae composed of a clathroid body of very irregularly and loosely anastomosing tubes. The cormus is narrower at the base than in the oscular region. The holotype is $1.5 \mathrm{~cm}$ high and $1 \mathrm{~cm}$ wide. There is one apical osculum. The paratype and additional material examined are fragmentary and the true shape of the cormus is not clear. Colour in life is yellowish beige and almost white in alcohol. No granular cells could be observed. Consistency is soft.

The skeleton is composed of regular triactines and regular to subregular tetractines. Tetractines is the most 
abundant spicule type (Figure 2B). Spicules are intermingled without any organization (Figure 2C). However, the spicules of the single tubes are overlapping and therefore form a thicker layer than is found in the most simply built species of Clathrina. The apical actines of the tetractines are pointing into the interior of the asconoid tubes. Triactines are most common in the outermost layer of the tube wall. Otherwise there is no special orientation of the spicules.

Spicules: Triactines: They are regular with slender and sharply pointed and conical actines (102-153-200 $\mu \mathrm{m} \mathrm{x}$ $7 \mu \mathrm{m})$ (Table 2, Figure 2).

TABLE 2. Spicule measurements of Clathrina brandtae sp. nov. Measurements are given as minimum, mean and maximum values. $\sigma=$ standard deviation. $\mathrm{n}=$ number of spicules measured.

\begin{tabular}{llllllll}
\hline Spicule & \multicolumn{2}{l}{ Length $(\mu \mathbf{m})$} & \multicolumn{5}{c}{ Width $(\mu \mathbf{m})$} \\
& $\min$ & $\max$ & mean & & mean & $\mathrm{s}$ & $\mathrm{n}$ \\
\hline Holotype, SMF 11867 & & & & & & & \\
Triactines & 102 & 200 & 153 & \pm 25.8 & 7.7 & \pm 0.5 & 30 \\
Tetractines & 100 & 235 & 153 & \pm 23.9 & 6.5 & \pm 1.0 & 30 \\
Apical actine & 50 & 138 & 82 & \pm 21.5 & 5.0 & \pm 0.7 & 30 \\
Paratype, SMF 11866 & & & & & & & \\
Triactines & 123 & 200 & 159 & \pm 21.6 & 8.3 & \pm 1.7 & 30 \\
Tetractines & 135 & 225 & 164 & \pm 20.2 & 7.3 & \pm 0.7 & 30 \\
Apical actine & 50 & 113 & 87 & \pm 5.1 & 5.1 & \pm 0.9 & 30 \\
\hline
\end{tabular}

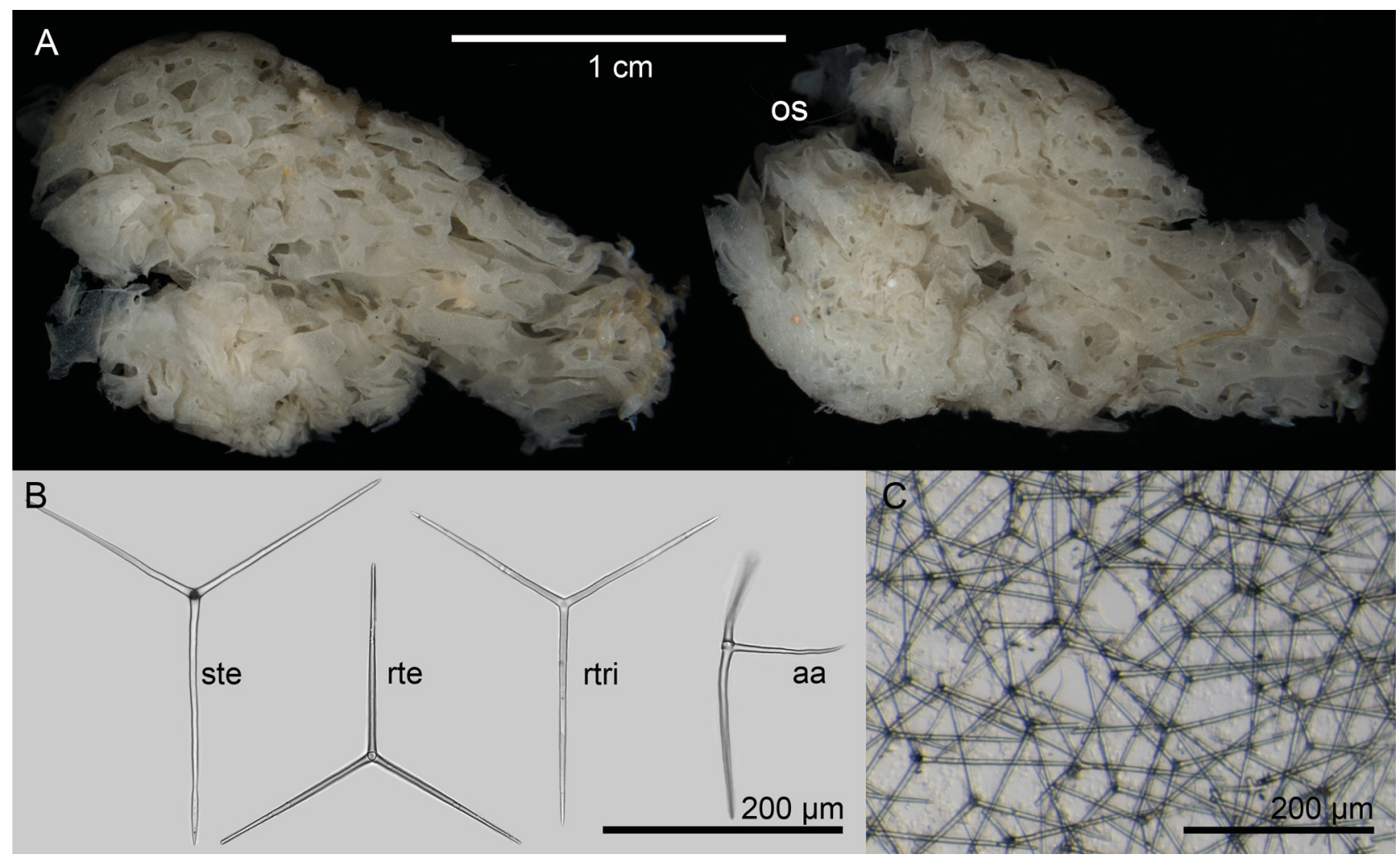

FIGURE 2. Clathrina brandtae sp. nov. A. Preserved Holotype from the Weddell Sea (SMF 11866) (os = osculum). B. Spicules of $C$. brandtae sp. nov. From left: ste $=$ subregular tetractine, rte $=$ regular tetractine, $r$ rri $=$ regular triactine and aa $=$ apical actine of a tetractine. C. Wall of asconoid tube seen from the interior.

Tetractines: The tetractines are similar to triactines. Some are slightly subregular. Apical actine is long, smooth, slightly curved and sharp (100-153-235 $\mu \mathrm{m} \times 6.5 \mu \mathrm{m}$, apical actine 50-87-113 $\mu \mathrm{m} \times 5.1 \mu \mathrm{m})$ (Table 2, Figure 2). 
Molecular identification: ITS1-5.8S-ITS2 sequences of the paratype has been deposited in GenBank under the accession number KC874655.

BLAST search confirmed the poriferan origin of the sequence, with Clathrina contorta (Minchin, 1905) as the closest match.

Distribution: Antarctic. Weddell Sea (this article and Barthel et al. 1997), Kemp Land (Koltun 1976), Kaiser Wilhelm II-Land (Brøndsted 1931) and the Winter Quarters (Jenkin 1908).

Remarks: The name Clathrina primordialis (Haeckel, 1872) has erroneously been used for different species of Clathrina from most oceans, representing the majority of Clathrina species with a skeleton consisting of spicules with sharply pointed actines (e.g. Arnesen 1900; Brøndsted 1931; Burton 1963). However, it is now well established that $C$. primordialis is a Mediterranean species with a skeleton solely composed of triactines (Klautau \& Valentine 2003), and recent examination of material from a wide geographical range, previously identified as $C$. primordialis, have resulted in description of a number of new species of Clathrina (e.g. Klautau \& Borojevic 2001; Rapp et al. 2001; Rapp 2006).

So far only one additional species of Clathrina is known from the Antarctic, namely Clathrina broendstedi Rapp et al., 2011 (Table 1). C. brandtae sp. nov. and C. broendstedi are very different as tetractines is the dominant spicule type in the former and the latter has only triactines. The loose and irregular anastomosis of tubes, large size of spicules, in combination with tetractines being the most abundant spicule type is rare within the genus. Based on organization of the cormus, organization of spicules as well as spicule size, C. biscayae Borojevic \& BouryEsnault, 1987 appears to be the closest. However, in C. biscayae the spicules are mainly parasagittal while in $C$. brandtae sp. nov. they are regular. Recently it has been shown that the genus Clathrina is not monophyletic (Rossi et al. 2011; Voigt et al. 2012). Based on molecular and morphological evidence Rossi et al. (2011) suggested that the genus should comprise only species with a skeleton composed of triactines, and species with additional di- and tetractines should be transferred to other genera and/or new genera should be erected. However, as none of the new clades were defined and given names, we choose to place $C$. brandtae sp. nov. provisionally in the genus Clathrina, awaiting formal description of the different groups within the old "Clathrina". In a molecular phylogeny based on the D2 region of $28 \mathrm{~S}$ as well as the entire region comprising the two spacers (ITS1 and ITS2) and the 5.8S ribosomal DNA, C. brandtae clusters within a well-defined group also containing C. biscayae and with Clathrina contorta as the most closely related species (Klautau et al. 2013).

\section{Family Leucettidae de Laubenfels, 1936}

\section{Genus Leucetta Haeckel, 1872}

Type species: Leucetta primigenia Haeckel, 1872 (by original designation).

Genus diagnosis: Leucettidae with a homogeneous organization of the wall and a typical leuconoid aquiferous system. There is neither a clear distinction between the cortex and the choanoskeleton, nor is a distinct layer of subcortical inhalant cavities present. The atrium may be reduced to a system of exhalant canals that open directly into the osculum or may be a large cavity (modified from Borojevic et al. 2002).

\section{Leucetta delicata sp nov.}

(Figure 3, Table 3)

Type locality: Eckström Shelf, Eastern Weddell Sea, Antarctica. SYSTCO station 71/48-1 at $70^{\circ} 23.94^{\prime} \mathrm{S}, 8^{\circ}$ $19.14^{\prime} \mathrm{W}, 602.1 \mathrm{~m}$ depth to $70^{\circ} 23.89^{\prime} \mathrm{S}, 8^{\circ} 18.67^{\prime} \mathrm{W}, 595.2 \mathrm{~m}$ depth.

Type material: Holotype SMF 11868, from the type locality.

Etymology: Named from the easily compressible and delicate structure of this species of Leucetta.

Additional material examined: BMNH25.11.1.35a. Pericharax carteri var. homorrhaphis (Polejaeff, 1883). Challenger collection. Tristan da Cunha. Antarctic. Discovery Collection. BMNH 10.2.7.1a. Leucandra microrhaphis Haeckel, 1872. Antarctic Belgica Expedition. BMNH07.8.6.65a. Leucandra primigenia var. leptoraphis (Jenkin, 1908) (now defined as Leucascus leptoraphis (Cavalcanti et al. 2013)). SMF 10359. Leucetta 
weddelliana Rapp et al., 2011. ANDEEP II Expedition. Weddell Sea. Leucetta antarctica. EASIZ Expedition. Weddell Sea, st. nr ps 39/29, 22.02.1996., $17^{\circ} \mathrm{S} 31.7^{\prime} \mathrm{W}, 503-518 \mathrm{~m}$ depth (Identified as Pericharax pyriformis in Barthel et al. 1997).

Description: The holotype is an ovoid and massive tube reaching $2.2 \mathrm{~cm}$ in height and $1.2 \mathrm{~cm}$ in width. Colour in life and in alcohol is beige (Figure 3A). Surface is smooth. Consistence is soft and compressible. The single apical osculum is naked. Below the osculum there is a small atrial cavity, smooth to slightly echinated because of single actines of choanosomal triactines piercing the atrial wall (may be an artefact due to collection or fixation). Numerous exhalant canals are dispersed in the atrium. The aquiferous system is leuconoid and the skeleton is disorganized, as typical in the genus. The cortex and the atrial walls are thin (Figure 3D-E), while the choanosome is thick. Triactines are the dominating spicules while very rare tetractines are found sparsely scattered in the choanosome. Sub-cortical spaces are present but poorly developed.
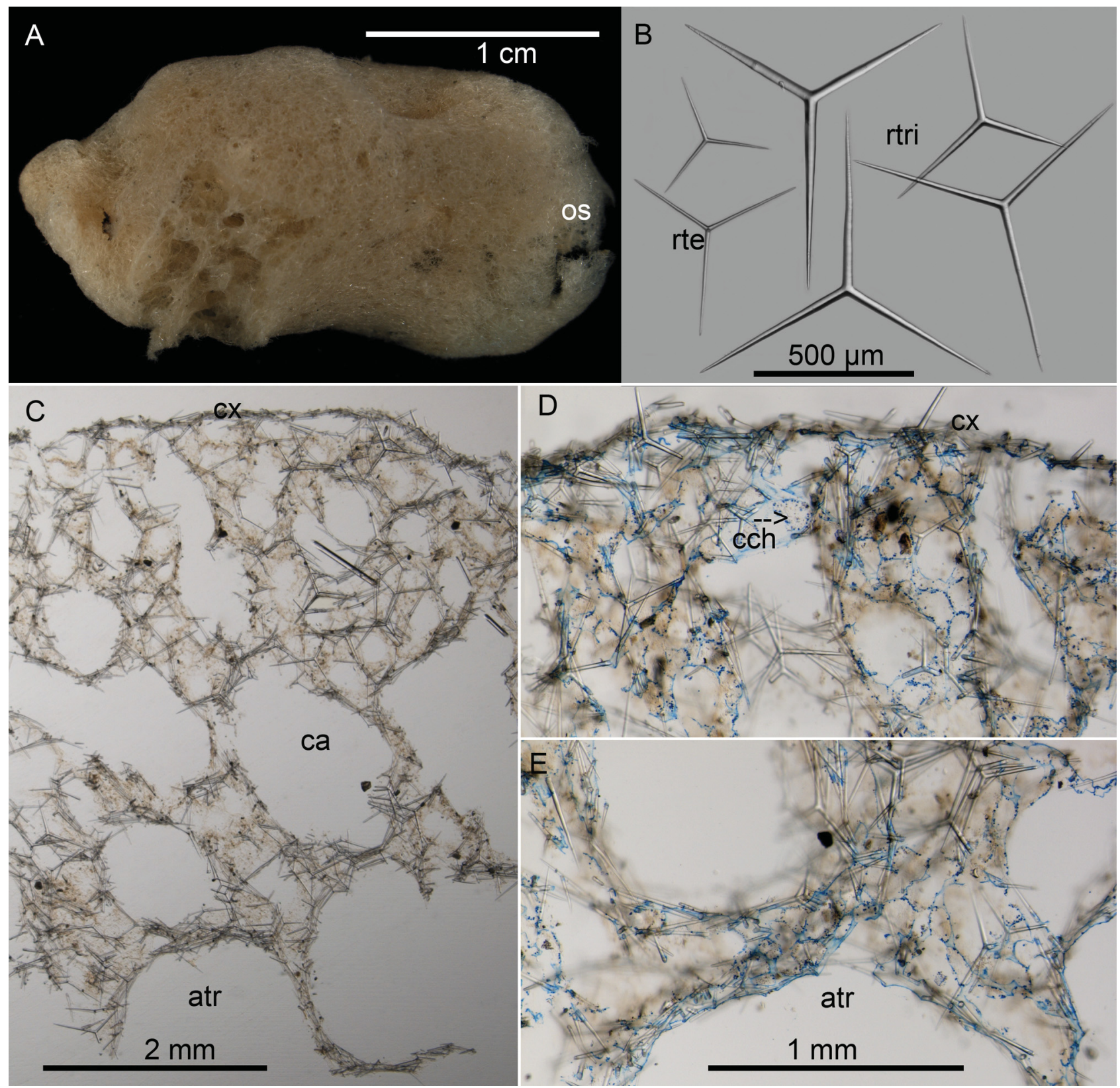

FIGURE 3. Leucetta delicata sp. nov. A. Preserved Holotype (SMF 11868). os = osculum. B. Spicules from L. delicata sp. nov. Bottom left: rte = regular tetractine with very short apical actine. Remaining spicules: rtri $=$ regular triactines of variable size. C. Cross section of the body wall. $\mathrm{cx}=$ cortex. $\mathrm{ca}=$ canal. $\mathrm{atr}=$ atrium. D. Cross section of the cortical region. $\mathrm{cx}=\mathrm{cortex}$. cch and arrow $=$ choanocyte chamber (scale bar as in E). E. Cross section of the atrial region. atr $=$ atrium. 
Spicules: Triactines: They are regular, equiradiate and equiangular. Actines are conical, with gradually tapering and sharply pointed tips. The size is variable, but the majority of the bigger spicules are tangentially arranged in the cortex. Some larger triactines can also be found in the choanosome (299-392-505 $\mu \mathrm{m} \times 23.4 \mu \mathrm{m})$ (Table 3, Figure 3).

Tetractines: The basal system of these spicules is similar to those of the triactines. Apical actines are very short and irregular (134-213-309 $\mu \mathrm{m} \times 13.1 \mu \mathrm{m}$, apical actine up to $15 \mu \mathrm{m}$ long) (Table 3, Figure 3).

TABLE 3. Spicule measurements of holotype of Leucetta delicata sp. nov. Measurements are given as minimum, mean and maximum values. $\sigma=$ standard deviation. $\mathrm{n}=$ number of spicules measured.

\begin{tabular}{llllllll}
\hline Spicule & \multicolumn{2}{l}{ Length $(\mu \mathbf{m})$} & \multicolumn{3}{c}{ Width $(\mu \mathbf{m})$} \\
& $\min$ & $\max$ & mean & $\mathrm{s}$ & mean & $\mathrm{s}$ & $\mathrm{n}$ \\
\hline Triactines & 299 & 505 & 392 & \pm 42.6 & 23.4 & \pm 3.9 & 50 \\
Tetractines & 134 & 309 & 213 & \pm 62.5 & 13.1 & \pm 1.7 & 9 \\
Apical actine & - & 15 & - & - & - & - & 2 \\
\hline
\end{tabular}

Molecular identification: A ITS1-5.8S-ITS2 sequence of the holotype has been deposited in GenBank under the accession number KC874654. BLAST search confirmed the poriferan origin of the sequence, with Leucetta chagosensis Dendy, 1913 as the closest match.

Distribution: Weddell Sea, known only from the type locality.

Remarks: Five species of Leucetta are at present known from Antarctic waters, namely L. antarctica Dendy, 1918; L. apicalis Brøndsted, 1931; L. gelatinosa (Jenkin, 1908); L. pyriformis (Burton, 1932) and L. weddelliana Rapp et al., 2011. Recent work on Leucetta, including the status of L. microrhaphis and L. primigenia has resulted in more limited distribution of these species and they are no longer considered part of the Antarctic fauna (Valderrama et al. 2009). Material representing species previously published as Leucetta spp or species potentially representing Leucetta from adjacent waters were studied to avoid confusion with $L$. delicata sp. nov. (listed under "additional material examined"). Our $L$. delicata sp. nov. bears the strongest similarities to $L$. antarctica and $L$. weddelliana. $L$. weddelliana and $L$. delicata sp. nov. both have triactines of very variable size, and the spicules cannot be divided into specific size classes. However, the triactines in L. delicata sp. nov are almost two times bigger than in $L$. weddelliana. In addition $L$. delicata sp. nov. presents rare tetractines dispersed in its choanoskeleton. Leucetta antarctica and L. delicata sp. nov. have triactines that are similar. However, the maximum size of triactines in L. antarctica is around $360 \times 35 \mu \mathrm{m}$ (Dendy 1918), while the average size is around $390 \times 23 \mu \mathrm{m}$ in L. delicata sp. nov. No tetractines have been found in L. antarctica, and while the tips of the actines are sharply pointed in L. delicata sp. nov they are slightly blunt in L. antarctica. In ongoing molecular phylogenetic analyses based on the D2 region of $28 \mathrm{~S}$ as well as the entire region comprising the two spacers (ITS1 and ITS2) and the 5.8S ribosomal DNA, comprising a high number of clathrinid taxa, Leucetta delicata sp. nov. clusters within a well-defined group also containing L. chagosensis and with an unidentified Antarctic species of Leucetta as the most closely related species (Klautau et al. in preparation).

\section{Concluding remarks}

Our results support the general trend that Calcarea appears as a highly diverse but not very abundant group of sponges in Antarctic waters (Barthel et al. 1997; Rapp et al. 2011; Downey et al. 2012). Even in the Weddell Sea where the sponge fauna is fairly well-known, a large proportion of the calcareous sponges in new collections represent new taxa. Our review of published information about calcareans in the area, supported by the work of Downey et al. (2012) and World Porifera Database (van Soest et al. 2012), resulted in a list of 50 species considered valid for Antarctic waters below $50^{\circ} \mathrm{S}$, which except from the Australian side represents the average position of the Antarctic Polar Front (Table 1). As many as 44 of these species are confined to Antarctic waters and only six species have been reported from elsewhere. Even though many species are represented by single records only, our results clearly indicate that there is an exceptionally high degree of endemism among Antarctic calcareous sponges. The work also revealed a great need of revision of most groups of calcareans in Antarctic waters. 


\section{Acknowledgements}

Thanks are due to Elena Gerasimova and the staff of the Biodiversity Laboratories (University of Bergen) for helping with preparation of plates and the molecular work. Claire Valentine from NHM London is thanked for loan of specimens and slides. We thank Deutsche Forschungsgemeinschaft for financial support to our study of sponges from the Antarctic SYSTCO I expedition (DFG project JA-1063/14-2). Two anonymous referees are thanked for their very useful comments on the manuscript. This is ANDEEP Publication Nr. \#161.

\section{References}

Adams, C.L, McInerey, J.O. \& Kelly, M. (1999) Indications of relationships between poriferan classes using full-length 18S rRNA gene sequences. Memoirs of the Queensland Museum, 44, 33-44.

Arnesen, E. (1900) Spongier fra den norske kyst. I. Calcarea. Systematisk katalog med bemerkninger og bestemmelsestabell. Bergens Museums Arbok, 1900, 5, 1-44.

Azevedo, F., Hajdu, E., Willenz, P. \& Klautau, M. (2009) New records of calcareous sponges from the Chilean coast. Zootaxa, $2072,1-30$

Barthel, D. \& Tendal, O.S. (1993) The sponge association of the abyssal Norwegian-Greenland Sea: species composition, substrate relations and distribution. Sarsia, 78, 83-93.

Barthel, D., Tendal, O.S. \& Gatti, S. (1997) The sponge fauna of the Weddell Sea and its integration in benthic processes. Berichte zur Polarforschung, 249, 44-52.

Borojevic, R. \& Boury-Esnault, N. (1987) Calcareous sponges collected by N.O. Thalassa on the continental margin of the Bay of Biscay: I. Calcinea. In: Vacelet, J. \& Boury-Esnault, N., Eds. Taxonomy oft he Porifera from the NE Atlantic and Mediterranean Sea. NATO Asi Series, G13. Berlin. Springer-Verlag, pp. 1-27.

Borojevic, R., Boury-Esnault, N., Manuel, M. \& Vacelet, J. (2002) Order Clathrinida Hartman, 1958. In: Hooper, J.N.A. \& van Soest, R.W.M., eds. Systema Porifera: a guide to the classification of sponges. New York: Kluwer Academic/Plenum Publishers, 1141-1152.

Borojevíc, R. \& Graat-Kleeton, G. (1965) Sur une nouvelle éspece de Sycon et quelques Démosponges récoltées par le „Cirrus“ dans Atlantique Nord. Beaufortia, 13, 81-85.

Boury-Esnault, N. \& Bézac, C. (2007) Morphological and cytological descriptions of a new Polymastia species (Hadromerida, Demospongiae) from the North-West Mediterranean Sea. In: Custódio, M.R., Lôbo-Hajdu, G., Hajdu, E. \& Muricy, G. (Eds). 2007. Porifera Research: Biodiversity, Innovation and Sustainability, 694 pp. Museu Nacional, Rio de Janeiro, Brazil, 23-30.

Brandt, A., Brix, S., Brökeland, W., Cedhagen, T., Choundhury, M., Cornelius, N., Danis, B., Mesel, I., Diaz, R.D., Gillan, D., Hilbig, B., Howe, J., Janussen, D., Kaiser, S., Linse, K., Malyutina, M., Brandao, S., Pawlowski, J., Raupach, M., Gooday, A. \& Vanreusel, A. (2007). The Southern Ocean deep sea: first insights into biodiversity and biogeography. Nature, 447, $307-311$.

Brøndsted, H.V. (1931) Kalkschwämme der Deutschen Südpolar-Expedition 1901-1903. Deutsche Südpolar-Exped., XX, Zool, 1-47.

Burton, M. (1932) Sponges. Discovery Reports, VI. pp. 237-392.

Burton, M. (1963) A revision of the classification of the calcareous sponges. London: British Museum (Natural History). 693 pp.

Cavalcanti, F.F., Rapp, H.T. \& Klautau, M. (2013) Taxonomic revision of the genus Leucascus Dendy, 1892 (Porifera: Calcarea) with revalidation of the genus Ascoleucetta Dendy \& Frederick, 1924 and description of three new species. Zootaxa, 3619, 275-314.

Dendy, A. (1918) Calcareous sponges. Australian Antarctic Exped. 1911-14. ser. C, VI(I), 1-17.

Dohrmann, M., Voigt, O., Erpenbeck, D. \& Wörheide, G. (2006) Non-monophyly of most supraspecific taxa of calcareous sponges (Porifera, Calcarea) revealed by increased taxon sampling and partitioned Bayesian analysis of ribosomal DNA. Molecular Phylogenetics and Evolution, 40, 830-843. http://dx.doi.org/10.1016/j.ympev.2006.04.016

Downey, R.V., Griffiths, H.J., Linse, K. \& Janussen, D. (2012) Diversity and distribution patterns in high southern latitude sponges. PLoS ONE, 7(7), e41672, 1-16. http://dx.doi.org/10.1371/journal.pone.0041672

Göcke, C. \& Janussen, D. (2013) Hexactinellida of the genus Rossella, of ANT XXIV/2 (SYSTCO I) Expedition—Antarctic Eastern Weddell Sea. Zootaxa, 3692(1), 102-122. http://dx.doi.org/10.11646/zootaxa.3692.1.6

Göcke, C. \& Janussen, D. (2011) ANT-XXIV/2 (SYSTCO) Hexactinellida (Porifera) and bathymetric traits of Antarctic glass sponges (incorporating ANDEEP-material); including an emendation of the rediscovered genus Lonchiphora. Deep-Sea Research II, 58, 2013-2021.

http://dx.doi.org/10.1016/j.dsr2.2011.01.006 
Hansen, G.A. (1885) Spongidae. Den norske nordhavsekspedisjon 1876-1878, 3, 1-25.

Janussen, D. (2010) First report on the Porifera (sponges) caught during the ANT XXIV-2, SYSTCO, programme. In: Bathmann, U. (Ed.), Report on Expedition of the Research Vessel "Polarstern" to the Antarctic in 2007/2008 (ANT-XXIV/ 2). Reports on polar and marine research, 604, 129-133.

Janussen, D. \& Rapp, H.T. (2011) Redescription of Jenkina articulata Brøndsted from the deep Eckström Shelf, E-Weddell Sea, Antarctica and a comment on the possible mass occurrence of this species. Deep-Sea Research II, 58, $2022-2026$. http://dx.doi.org/10.1016/j.dsr2.2011.01.007

Janussen, D. \& Reiswig, H.M. (2009) Hexactinellida (Porifera) from the ANDEEP III Expedition to the Weddell Sea, Antarctica. Zootaxa, 2136, 1-20.

Janussen, D., Schrödl, M., Schwabe, E., Ebbe, B., Robert, H., Wadley, V., Würzberg, L., Zapata Guardiola, R. \& Brandt, A. (2010). Preliminary report on AGT catches during ANT XXIV-2.- In: Bathmann, U. (Ed.), Report on Expedition of the Research Vessel "Polarstern" to the Antarctic in 2007/2008 (ANT-XXIV/2). Reports on polar and marine research, 604: pp. 124-128.

Janussen, D. \& Tendal, O.S. (2007) Diversity and distribution of Porifera in the bathyal and abyssal Weddell Sea and adjacent areas. Deep-Sea Research II, 54 (16/17), 1864-1875.

Janussen, D., Tabachnick, K.R. \& Tendal, O.S. (2004) Deep-sea Hexactinellida (Porifera) of the Weddell Sea. Deep-Sea Research Part II, 51/14-16, 1857-1882. http://dx.doi.org/10.1016/j.dsr2.2004.07.018

Janussen, D., Rapp, H.T. \& Tendal, O.S. (2003) A myth vanished: Calcareous sponges are alive and well at abyssal depths. Deep-Sea Newsletter, 32, 17-19.

Jenkin, C.F. (1908) The Calcarea of the National Antarctic Expedition 1901-1904. Nat. Hist. Rep., 4, 1-52.

Klautau, M., Azevedo, F., Cóndor-Luján, B., Rapp, H.T., Collins, A. \& Russo, C.A.M. (2013) A molecular phylogeny of the Order Clathrinida rekindles and refines Haeckel's taxonomic proposal for calcareous sponges. Integrative and Comparative Biology, pp 1-15. http://dx.doi:10.1093/icb/ict039

Klautau, M. \& Valentine, C. (2003) Revision of the genus Clathrina (Porifera, Calcarea). Zoological Journal of the Linnean Society, 139, 1-62. http://dx.doi.org/10.1046/j.0024-4082.2003.00063.x

Klautau, M. \& Borojevic, R. (2001) Calcareous sponges from Arraial do Cabo - Brazil (I: the genus Clathrina). Zoosystema, 23, 395-410.

Koltun, V.M. (1976) Porifera Part I: Antarctic sponges. B.A.N.Z. Antarctic Research Expedition 1929-1931. Reports ser. B. IX(4), 147-198.

Koltun, V.M. (1970) Sponge fauna of the north-western Pacific from the littoral to the ultra-abyssal depths. Trudy Inst. Okean. Akad. Nauk SSSR, 86, 165-221 (in Russian).

Lôbo-Hajdu, G., Guimarães, A.C.R., Salgado, A., Lamarão, F.R.M., Vieiralves, T., Mansure, J.J. \& Albano, R.M. (2004) Intragenomic, intra- and interspecific variation in the rDNA ITS of Porifera revealed by PCR-Single-Strand conformation polymorphism (PCR-SSCP). Bollettino dei Musei e degli Istituti Biologici dell'Universitá di Genova, 68, 413-423.

Manuel, M., Borchiellini, C., Alivon, E., Le Parco, Y., Vacelet, J. \& Boury-Esnault, N. (2003) Phylogeny and evolution of calcareous sponges: Monophyly of Calcinea and Calcaronea, high level of morphological homoplasy, and the primitive nature of axial symmetry. Systematic Biology, 52(3), 311-333. http://dx.doi.org/10.1080/10635150309322

Plotkin, A., Gerasimova, E. \& Rapp, H.T. (2012) Phylogenetic reconstruction of the Polymastiidae (Demospongiae: Hadromerida) based on morphology. Hydrobiologia, 687, 21-41. http://dx.doi.org/10.1007/s10750-011-0823-0

Plotkin, A.S. \& Janussen, D. (2008) Polymastiidae and Suberitidae (Porifera: Demospongiae: Hadromerida) of the deep Weddell Sea, Antarctic. Zootaxa, 1866, 95-135.

Polejaeff, N. (1883) Report on the Calcarea dredged by HMS "Challenger" during the years 1873-1876. Rep. Sci. Results voyage "Challenger", Zoology, 8, 1-76.

Rapp, H.T. (2006) Calcareous sponges of the genera Clathrina and Guancha (Calcinea, Calcarea, Porifera) of Norway (northeast Atlantic) with the description of five new species. Zoological Journal of the Linnean Society, 147, 331-365. http://dx.doi.org/10.1111/j.1096-3642.2006.00221.x

Rapp, H.T., Janussen, D. \& Tendal, O.S. (2011) Calcareous sponges from abyssal and bathyal depths in the Weddell Sea, Antarctica. Deep-Sea Research II, 58, 58-67. http://dx.doi.org/10.1016/j.dsr2.2010.05.022

Rapp, H.T., Klautau, M. \& Valentine, C. (2001) Two new species of Clathrina (Porifera, Calcarea) from the Norwegian coast. Sarsia, 86, 69-74.

Rossi, A.L., Russo, C.A.M., Solé-Cava, A.M., Rapp, H.T. \& Klautau, M. (2011) Phylogenetic signal in the evolution of body colour and spicule skeleton in calcareous sponges. Zoological Journal of the Linnean Society, 163, 1026-1034. http://dx.doi.org/10.1111/j.1096-3642.2011.00739.x

Tanita, S. (1959) Biological results of the Japanese Antarctic Expedition 1. Sponges. Special Publications from the Seto Marine Biological Laboratory, Series 1, 1-8. 
Valderrama, D., Rossi, A.L., Solé-Cava, A.M., Rapp, H.T. \& Klautau, M. (2009) Revalidation of Leucetta floridana (Haeckel, 1872) (Porifera, Calcarea): a widespread species in the tropical western Atlantic. Zoological Journal of the Linnean Society, 157, 1-16. http://dx.doi.org/10.1111/j.1096-3642.2009.00522.x

Van Soest, R.W.M., Boury-Esnault, N., Vacelet, J., Dohrmann, M., Erpenbeck, D., De Voogd, N.J., Santodomingo, N., Vanhoorne, B., Kelly, M. \& Hooper, J.N.A. (2012) Global diversity of sponges (Porifera). PLoS ONE, 7(4), e35105, 1-23. http://dx.doi.org/10.1371/journal.pone.0035105

Van Soest, R.W.M., Boury-Esnault, N., Hooper, J.N.A., Rützler, K., de Voogd, N.J. et al. (2012) World Porifera Database. Available from: http://www.marinespecies.org/porifera (Accessed 28 Nov. 2012)

Voigt, O., Wülfing E. \& Wörheide G. (2012) Molecular phylogenetic evaluation of classification and scenarios of character evolution in calcareous sponges (Porifera, Class Calcarea). PLoS ONE, 7(3), e33417, 1-16. http://dx.doi.org/10.1371/journal.pone.0033417

Wörheide, G. \& Hooper, J.N.A. (1999) Calcarea from the Great Barrier Reef. I: Cryptic Calcinea from Heron Island and Wistari Reef (Capricorn-Bunker group). Memoirs of the Queensland Museum, 43, 859-891. 